\title{
Changes of the Political and Legal Systems: Judicial Autonomy
}

\author{
Zoltán Fleck ${ }^{1}$ (D) \\ ${ }^{1}$ Eötvös Loránd University, Center for Theory of Law and Society, Budapest, Hungary \\ Corresponding author: zfleck@ajk.elte.hu
}

(Received 14 September 2021; accepted 21 September 2021)

\begin{abstract}
This Article summarizes the features of modern non-democratic legal systems and draws the relevant conclusions. Some of these systemic issues have long-term consequences. The Article illustrates the defining effects of the historical traditions with concrete examples based on empirical researches. Judicial independence as part of the rule of law is not only institutional guarantees but cultural, mental dispositions too. This Article shows how non-democratic legal heritage led to backsliding democracy in post-communist Hungary. However relative autonomy of judges could emerge during the last three decades of the communist rule, skills and habits of professional self-defense could not stabilize.
\end{abstract}

Keywords: Authoritarianism; socialist legal culture; legal traditions; political transformation; judiciary; judicial independence

\section{A. Introduction}

Proper conceptual tools are needed for understanding the nature and dynamism of the political pressures challenging the autonomous spheres of society and such public realms as the judiciary. Experts are surprised to see that the post-communist legal professions, especially judges, have little ability to defend their autonomy. ${ }^{1}$ Judges under the pressures of authoritarian politics can only use the tools at their disposal, the toolkit that has gradually evolved over the institutionalization of judicial independence. The cultural and historical conditionality of actual autonomy of the judiciary became a bitter experience during the backsliding of post-communist democracies. ${ }^{2}$ Four decades of communist rule can only explain the current situation together with long-term historical antecedents. Judicial toolkits deployable against political pressures-individual, collective, and organizational routines of defending autonomy-are the output of a slow learning process. A wider context matters.

According to historical experience, the lives of autocratic systems are much longer than those of democracies. Consolidated democracy is a rare phenomenon. ${ }^{3}$ The "authoritarian effect" is always vivid, especially in those societies where the non-democratic past has finished recently, if at all.

\footnotetext{
${ }^{1}$ See Maria Popova, Politicized Justice in Emerging Democracies: A Study of Courts in Russia and Ukraine (2012).

${ }^{2}$ Judicial autonomy as an essential part of liberal constitutionalism has a multilevel structure. The autonomy of the third branch in the system of division of power means guarantees against the executive and the legislative powers. At the individual level, judicial autonomy means the freedom of the sitting judge during interpreting the law, and the guarantees of the judicial status. All of these elements are integral parts of the concept of judicial autonomy; consequently, judicial autonomy is a broader concept than independence.

${ }^{3}$ See Sheri Berman, Democracy and Dictatorship in Europe: From the Ancien Regime to the Present Day (2019).
} unrestricted re-use, distribution, and reproduction in any medium, provided the original work is properly cited. 
Thus, any analysis of the institutional settings of the former period must be embedded in a longterm historical interpretation. This way it may give explanations on the matter of remnants of authoritarian culture. At the same time, the legal system consists of institutions. Moreover, law is an institution with the functions of solving problems and structuring society. ${ }^{4}$ Thus, the rules, organizations, professions, and the relationship between them are the subjects of the research based on a historical institutionalist conceptual framework. But ideas matter, not only institutions: Before the period under study here, the ideational, theoretical elements of the legal system-namely legal science, theory, and education-missed the basic concept of the Rechtsstaat. This jurisprudential, conceptual weakness does not simply mirror the characteristics of the communication between institutional elements of the legal system, but supplements the patrimonial, autocratic functioning of the legal system. The history of institutional development and theoretical heritage are both matters in the evolution of judicial system. On this starting point, we should take into consideration a more distant past for depicting the context of the judicial autonomy during communist rule. Communist rule as a general source of backsliding in Eastern Europe is a superficial explanation. ${ }^{5}$

The structure of this Article follows these principles. After summarizing some relevant historical tendencies of modern Hungary in Section B, I describe the main characteristics of the communist legal systems in Section C, and the dictatorial law in general in Section D. The development of the judicial system in Section $\mathrm{E}$ and the limited independence of the judiciary, in Section F, are the knowledge needed to understand the possibilities of judicial self-defending activities in Section G. The changing political use of the concept of socialist legality reflects the dynamics of communist rule in Section $\mathrm{H}$.

\section{B. Authoritarian Legal Culture: The Burden of the Past}

The modern Hungarian state, after 1867, remained patrimonial without a modern bureaucracy, a noble-controlled structure in which land-owning nobility controlled the organs of local governments and successfully broke the central absolutism. ${ }^{6}$ Weak absolutism meant also that representative institutions were only instruments of noble privileges; the "constitutional question" was only defending the interests of the landowning nobles from the absolutist Emperor. In this patrimonialist infrastructure, even after the monarchical modernization in the second half of the 19th century, only fragments of the Rechtsstaat were enacted; mainly property and strictly personal rights, but political rights were regulated by ministerial decrees and the police under the autocratic presumption. ${ }^{7}$ In the shadow of the strong power and wide discretion of the executive, the judiciary became formally independent in $1869,{ }^{8}$ but judges continually applied executive decrees and were incapable of defending individual rights and interests. In general, according to the very essence of the political and legal thinking, rights remained mere concessions from the state, which represented the interest of the Nation. Counterbalancing conservative, executive interests was illusory without Rechtsstaat guarantees, codified civil rights, and with truncated parliamentarism in which the oligarchic noble interest represented the Nation. The

\footnotetext{
${ }^{4}$ See John Bell, The Importance of Institutions, in The Method and Culture of Comparative Law 207-21 (Maurice Adams \& Dirk Heirbant eds., 2014).

${ }^{5}$ See Ivan T. Berend, Economic History of a Divided Europe: Four Diverse Regions in an Integrating Continent (2020).

${ }^{6}$ See Thomas Ertman, Birth of the Leviathan: Building States and Regimes in Medieval and Early Modern EUROPE (1997).

${ }^{7}$ See Péter lászló, Hungary's long Nineteenth Century: Constitutional and Democratic Traditions in a European Perspective (2012).

${ }^{8}$ Two years after the Austro-Hungarian Compromise, the Act IV of 1869 on the exercise of the judicial power institutionalized the separation of power by declaring that the judicial power must be separated from the public administration and that judges will proceed only by acts, decrees, and custom of law.
} 
autocratic principle survived the Habsburg modernization and state apparatus, including the judiciary, remained in the hands of noble strata. In the Hungarian backwardness, meaning the lack of modern, rational bureaucracy, the strong interconnectedness of land ownership, noble status, lineage, and office played a strong role.

The Grossdeutsche ideology in the Austrian leading circles of bureaucracy and elite made Hungarian thinking on the "constitutional question" defensive. Constitutionalism as a bastion against the monarchical absolutism - and German centralism - was based on the traditional patrimonial interest and a mere simulation of parliamentarism. ${ }^{9}$ The Austro-Hungarian Compromise $^{10}$ (1867) was a mixture of absolutistic and constitutional elements, without the possibility of solid absolutism and real constitutionalism; parliamentary decision-making did not play a considerable role. The state apparatus on the Hungarian side was dominated by the reactionary, nationalist, semi-professional gentry while the Austrian bureaucracy had a conservative German orientation. Consequently, in Hungary the factual one-party system functioned as a necessary shield against the strong Dynasty; thus, limited democratization of the political sphere could be legitimized by a "constitutional" argument. In the dualist Monarchy, there was no common Parliament, only a common executive and common issues such as foreign affairs, defense, and finance. Hungarian political forces could effectively act in national interests if they showed unified force in the Hungarian Parliament. Consequently, one-party structure, a strong, stable political bloc, functioned as a safeguard upwards against the Dynasty, while the limited rights and discretionary executive exerted control downwards against social unrest. ${ }^{11}$ The whole system was stabilized by the military, the dynasty, and the bureaucracy from the Austrian side: The parliament, separation of powers, constitutional rights, and Rechtsstaat did not play a role. Constitutional development was highly uneven in Central Europe until 1945, as Hungarian constitutional structure remained far from the German Rechtsstaat, and the separation of powers was weak compared to that of Austria and Czechia. ${ }^{12}$

This uneven and unfinished modernization, backwardness, and stagnation, dynastic absolutism, and paternalistic etatism limited the birth of a strong middle-class based civil society. ${ }^{13}$ Middle class in this region was made up of middle and petit noble strata. In Austria the Bildungsbürgertum (educated middle class) and officeholders were as strong as the heirs of the Enlightened absolutistic reforms and effectively kept in hands the state-raison. However, in Hungary, the gentry dominated the administrative apparatus, and even the emerging bourgeoisie adopted to the values and lifestyle of nationalistic conservative Hungarian gentry. In Austria, the dynastic patriotism could give way to the new state-patriotism and constitutionalism while in the Hungarian elite constitutionalism meant only opposing the Habsburg centralism. During the crises of the liberal era, when the advanced, monopoly capitalism emerged at the end of the 19th century as the characteristic figure of the declassified middle strata, the gentry had turned against foreign capitalism and state modernization and taken an ethnonationalist identity.

The long-term effect is that the Hungarian gentry has occupied the state administration and gradually infused it with the ideology of a national battle against the Habsburg monarchy. ${ }^{14}$ The

\footnotetext{
${ }^{9}$ See Hanák Péter, A dualizmus válságának problémái a XIX. század végén [The Problems of the Crisis of Dualism at the End of the 19th Century], in MAGYARORSZÁG A MONARCHIÁBAn (1975).

${ }^{10} \mathrm{After}$ almost a two-decade long military government which was retaliation for the war of independence and dethronement of 1848-49, the House of Habsburg and the Hungarian political forces agreed on a new dualistic state structure. The Treaty paved the way for modern state and economic development.

${ }^{11}$ Between 1875 and 1905, the liberal party (Szabadelvü Párt).

${ }^{12}$ See David Kosař, Jiri Baroš \& Pavel Dufek, The Twin Challenges to Separation of Powers in Central Europe: Technocratic Governance and Populism, 15 Eur. Const. L. REv. 427 (2019).

${ }^{13}$ See Hanák Péter, Társadalmi struktúrák a 19. századi Közép-Európában [Social Structures in 19th Century Europe], in TÖRTÉNELMI SZEMLE 159-77 (1997).

${ }^{14}$ See Nagy Endre, A dzsentroid hivatalnok a Monarchia korában [Gentry Clerks During Monarchy], in Szocio KALANDOZÁSOK (2003).
} 
professionalization of the administrative apparatus was slow. In the local administrative positions, possession of a degree became compulsory only after 1883, however, the law gave exemptions for positions already occupied. The gentry's mentality in the administration and the judiciary, nationalistic, the militaristic "canon of honor" remained the counterforce of the foreign rule (rational modernization) embodied by the Habsburg Crown. In this system of values, the term "bureaucratic" meant un-national, inhuman; it had only a pejorative meaning, which long survived during the post-war communist rule. Both real capitalism and real rational bureaucracy were missing in Hungary. The local county administration (vármegyei igazgatás) was vested with mythic importance as a historical bulwark against the Western parliamentarism; the local noble administration was the historical assurance of the survival of the nation, against which all assaults failed. This illusory role of the local county noble administration was against the Western-style reformers and foreign forces. The same illusory meaning and mysticism encompassed the concept of "constitutionalism," in which the Holy Crown theory played the central role. In this condition state bureaucracy could not serve as social integrator comparing to the German apparatus. ${ }^{15}$

Beside the rejection of parliamentarism as detrimental to the unity of the Nation, state office, public administration with its professionalism and civil servant spirit, filled the gaps between social strata. This non-democratic representation, rather cooptation of the social groups, made social compromise possible while serving the common interest. At the same time in Hungary the declassed noble strata, the gentry dominated the state and local bureaucracy and used the public law issues and constitutional questions for their particular interests. It is not a surprise that in a country which was administered exclusively by nobles, the centralizing bureaucratic reforms of the Habsburg Monarchy are mostly derailed. In the public thinking, this noble interest appeared as a national constitutional issue. By the end of the 18th century the protection of noble interests against the absolutism became the so-called public law problem. The constitutional question was crystallized as a sharp opposition between the patrimonial nation and the foreign Crown. The phrases of "ancient constitution," the "constitutional traditions of the Nation," and the doctrine of the Hungarian Holy Crown of St. Stephen served as the conceptual basis of the political discourse and, consequently, the Crown was pushed out from the body of the nation. ${ }^{16}$

During the interwar period, most Eastern European countries built nationalistic, right-wing regimes. The revolt against the Western liberalism, free-markets, and parliamentary democracy was characteristic from the dawn of the century and took a radical form after the first world war . The pessimism of the region was fed on the unsuccessful modernization attempts. In Hungary, the counter-revolutionary regime of Horthy built its legitimacy on territorial revision, and thus drifted more and more towards the fascist alliance. ${ }^{17}$

Taking advantage of the weak traditions of separation of powers, patrimonial social structure, and limited suffrage, Horthy, as Head of the State, successfully consolidated the authoritarian, centralized political system. Some other factors also helped this process: The trauma of territorial loss and the short communist power grab in 1919. During the interwar period the basic constitutional structure of power had not changed, but its authoritarian traits intensified. Judicial power remained under the political and ideological influence of the executive. The selection of judges was in line with the highly conservative and closed structure of the Hungarian state apparatus. ${ }^{18}$

\footnotetext{
${ }^{15}$ See Wolfgang Seibel, Beyond Bureaucracy: Public Administration as Political Integrator and Non-Weberian Thought in Germany, 70 PuB. Admin. Rev. 719 (2010).

${ }^{16}$ See Szijártó István, The Birth of the Constitution in Eighteenth Century Hungarian Political Thought, in A HISTORY OF THE Hungarian Constitution (Hercher Lorman ed., 2018); László Péter, The Holy Crown of Hungary, Visible and Invisible, 81 The Slavonic and East Eur. Rev. 421 (2003).

${ }^{17}$ Ivan T. Berend, The Crises Zone of Europe: An Interpretation of East-Central European History in the First Half of the Twentieth Century (1986).

${ }^{18}$ See Peter Takács, On Stateform of Hungary between 1920 and 1944: Applicability of the Term "Monarchy without a King", 10 J. Eur. Hist. L. 139 (2019).
} 
Before analyzing the characteristics and history of the Hungarian judicial system in Sections E through $\mathrm{H}$, it seems necessary to clarify the theoretical models of non-democratic law in Sections $\mathrm{C}$ and $\mathrm{D}$, because of their strong influence on the historical development of Hungary.

\section{The Dynamism of the Communist Legal System}

The early historical epoch of revolutionary justice in Soviet Russia-from the Revolution until the 1936 Constitution-when the People's Court made decisions on the revolutionary conscience, gave its place to the formality, but laicization did not disappear entirely. The concept of law in its formal sense from this time was similar to that of the Western states, however without universal values of rights, autonomy, and dignity, and without a separation of power system.

It is symptomatic that already the second decree of the All-Russian Central Executive Committee on the judiciary in 1918 February made the old statutes of 1864 compulsory for District People's Courts. According to this rule, judges had to apply the decrees of the government and in case of absence of a decree, the socialist consciousness could act as "guidance" for judges. ${ }^{19}$ For the middle of the century lay elements of the socialist legal system were limited to the lay members of judicial bodies, and the Comrade's Courts, which had authority in petty crime cases only. The program of modernization and even the aim of reshaping society, forming the Homo Sovieticus ${ }^{20}$ and socialist community, could be achieved by central autocratic formal institutions. The development of the Soviet-type law was characterized by the oscillation between legal regulation and lawlessness. "In fact, anarchy and lawlessness were present; and while the regime depended on anarchy for the success of the revolution, it attempted to put some order into the operation of its own courts by the correlation of this activity to such laws as were available." 21 From the very beginning, the number of decrees grew swiftly as the guiding principles for judges. The first turn when the bureaucratic technique, formal standards of working of legal institutions, especially courts returned, was the New Economic Policy (NEP) and the Soviet Civil Code of 1922.

The Stalinist totalitarianism used legal tools intensively, with law playing a central role in all aspects of the policy of the party-state, because only the traditional role and form of the law fitted to the wants of the official policy of planned progress. The dominant method of change and expansion became law-making, legal decrees, codification, and their lawyerly implementation. The changes of the Western legal culture also complicated the situation, as the expansion of the state and the growth of public law became common in Western states. ${ }^{22}$ Institutional formality, legal formalism, and dogmatic basis have their own potential. These forms were open for autocratic usage, but also for reforms, distancing them from harsh dictatorship.

From this perspective, the Soviet state and law was not entirely without normative antecedents, it was not made from scratch. It is true that the Soviet rule was initially a sharp break with the past, including its legal traditions. It dissolved legal institutions, negated the formal structures of law, and was based on laicization and ideologic reshaping of the normative sphere of society-the legalism was under harsh attack. ${ }^{23}$ But it turned out, swiftly, that legal formalism was necessary from very pragmatic political causes. Urgent restoration of the legal rationality was necessary because of the danger of economic collapse and military weakness. This restoration could be built on the former czarist modernization and adaptation of civil law institutions. But the relation to law remained contradictory for the long run, an oscillation of legalism and legal nihilism as a system characteristic could be detected until the end of the history of the communist rule. The source of

\footnotetext{
${ }^{19}$ See Harold J. Berman, Justice in the U.S.S.R. An Interpretation of the Soviet Law (2013).

${ }^{20}$ Term used for the new kind of people created by the Soviet Communism in an ironic, critical sense as conformist, servile double-thinker. See Aleksandr Zinovyev, Homo Sovieticus (1986).

${ }^{21}$ See Kazimierz Grabowski, Soviet Legal Institutions: Doctrines and Social Functions (1962).

${ }^{22}$ See Harold Berman, Law and Revolution: The Formation of the Western Legal Tradition (1985).

${ }^{23}$ See Hans-Petter Graver, Law and the Russian Revolution: A Comparison with the Nazi Approach to Law, in RUSSIAN Revolutions of 1917: Scandinavian Perspectives (Alla Pozdnakova ed., 2019).
} 
this legal nihilism was the constant subordination of law to politics as a stable part of the socialist legality. Party command and unity of power made both doctrine and the formality of state rules relative. But procedural formality, balancing between strict interpretation and ideological contents, was also present. The institutional homogeneity, the adaptation of Western legal formalism with the very basis of 19th century czarist modernization, was not without consequences.

\section{Dictatorial Law}

In the process of understanding the Hungarian pre-democratic past and its effects on the current backsliding, the comparison of totalitarian legal systems could be informative. HansPetter Graver has strong arguments on the basic differences between Nazi and Communist law, saying that in Nazi Germany essential elements of the law remained intact, at least until the end of the 1930s; institutional autonomy, professionalism, specialization and the relative supremacy of the law were substantial remnants of the German Rechtsstaat. Consequently, belief of judicial independence and culture of autonomy could be preserved, as opposed to the communist law in which these elements were missing. According to this explanation, the communist regimes lacked the central features of Normative State. ${ }^{24}$ Ernst Fraenkel's excellent work on Nazi Germany would not be an appropriate conceptual framework for analyzing them. ${ }^{25}$ In the Communist part of Europe, there was no continuity of legal rationality and legally limited state with the term of Fraenkel Normative state. The duality came later as the route of reform of the communist legal systems. However, this dynamism could not be built in considerable traditions, the "socialist Rechtsstaat" did not emerge entirely from scratch. During the process of slow emancipation of law from ideological dominance legal instrumentalism became stronger. On the very basis of this progress, the institutional building of continental type of law could serve both the totalitarian centralization and authoritarian political softening. The emancipation of legal rationality was a living option in the second half of the Communist rule on the basis of continental hierarchical institutions, formal nonrechtsstaatlich legalism. The most obvious example is the development of judicial independence from direct political intervention to growing normativity and restraint from extra-legal measures. This tendency as option of development was inherent in the continental formalism. All over the socialist world, to a greater or lesser extent, a slow professionalization of the staff, the professional criteria of selection, pushed back the pure political reliability. Nevertheless, it did not disappear from the selection of court presidents. The reinvention of the Romanist civil law tradition without integral theory, a concept of the Rechtsstaat, caused rigid formalism—strict adherence to the text of the law-even to low level state commands. ${ }^{26}$ The legal reasoning of judges remained formalistic and partly ideologically driven till the fall of Communism. ${ }^{27}$ This formalist approach must not be confused with positivism, but without doubt played important role as shield against pure ideological or political pressures. Judges during the second half of socialist Hungary could defend themselves against the personal, political influences by referring to legal duties. ${ }^{28}$ The relevance of formalism was high in a system where Western legal tradition remained weak and distorted. Similar to the Langdell-era in the United States, the invention of legal tradition, institutionalizing

\footnotetext{
${ }^{24}$ Ernst Fraenkel evaluated the Nazi system before the war period with the concept of duality of normative and prerogative state. Normative means that formal legal rationality matters, while prerogative side of the state is based on the raw commands (Massnahmen) of the dictator. See Ernst Fraenkel, The Dual State: A Contribution to the Theory of Dictatorship (1941).

${ }^{25}$ See Jens Meierhenrich, The Remnants of the Rechtsstaat, An Ethnography of Nazi Law (2019).

${ }^{26}$ See Zdenek Kühn, The Judiciary in Central and Eastern Europe: Mechanical Jurisprudence in TRANSFORMATION? (2011).

${ }^{27}$ See Maria Los, Communist Ideology, LaW and Crime. A Comparative View of the USSR and Poland (1988).

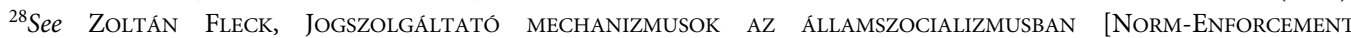
Mechanisms in State Socialism] (2001).
} 
roles, behaviors, and educating of lawyers needed strong formalism. ${ }^{29}$ The formalist legal methodology helped to bring about professionalism from the initial particularism and lay justice. ${ }^{30}$

The New Economic Policy (1921-28), then the Stalinist constitution-making (1936), was a strategic step back from the revolutionary legal conscience with the help of Western institutions. The illusion of the withering of state and law faded away under the pressure of institution-making. As a consequence, the Soviet legal system became more similar to its Western counterpart. However, the original Marxist thesis of the death of the state as an ideological milestone remained without any effects on everyday practice. Throughout the history of the socialist type of law, there was a lasting gap between official ideology in political texts and brochures and everyday practice. ${ }^{31}$

According to the autocratic logic, the political and economic dangers told political leaders that formalism serves the interest of the people, and from this strategic decision nihilism turned into treachery; Vishinsky, the legendary and dreaded Prosecutor General, replaced Pashukanis, the Pope of the Soviet legal theory in pre-Stalinist period. "Utopia had been replaced by legal orthodoxy." 32 The need for a strong central state and western-type institutions culminated in the creation of the 1936 Constitution and the Judicial Act (1938), by which the very basis of duality had been established: Normality and terror. This duality, coexistence of law and force is the normal state of affairs, as no authoritarian system can function without an elementary level of normative regulation as a tool of social control. ${ }^{33}$ Nor can rule of law system live without an elementary level of coercive power. The general coercive seed of the law makes formalism a suitable tool for any authoritarian structure. ${ }^{34}$ On the political surface, dictatorial rule has some stable elements in relation to judicial power, as constant ideological attacks on judicial autonomy, the low salary of judges, and the curtailing of the judicial interpretation all make surprising shows of judicial independence rare. Pressures on judges to interpret law in line with official ideology and technical formalism serves the interest of the authoritarian state without contradictions. But formalism in the hands of judges could be used for defending themselves from the political influence. The central institution of socialist normativity, which itself embodied the duality of formalism and political ideology was prosecutor's office (procuracy). "Prokuratura" from the beginning played a key role in socialist states as an unlimited, hierarchical, and militant structure - the strongest legal institution. Thus, the concept of socialist legality formed and used by prosecutorial office and the changes of it mirrors the line between law and ideology.

\section{E. Legal Thinking}

Among the political, cultural, and social conditions of the autocratic regimes, the concept and evolution of legality play explicit roles. As a part of the legal thinking and visions of law, the pathway of legal thinking has its own force in shaping legal reality. Legality restricts the scope of judicial interpretation, binding judges to official normative text. The method and political context of modernizing the legal system strongly influence the present function of the institutions: “. . . in current judicial practice a literal interpretation of legislation has dominated, while any systematic interpretation based on definite legal principles seems to have been avoided, especially in relation

\footnotetext{
${ }^{29}$ Christopher Columbus Langdell was the first legendary Dean of Harvard Law School in the last third of the 19th century. His name is merged with case method of teaching law, later blamed as a decontextualized for his formal method of lawyering and textualist interpretation.

${ }^{30}$ See Eric Engle, The Fake Revolution: Understanding Legal Realism, 47 WASHBURN L.J. 653 (2008).

${ }^{31}$ See Inga Markovits, The Death of Socialist Law?, 3 ANN. Rev. L. \& Soc. ScI. 233 (2007).

${ }^{32} I d$. at 236.

${ }^{33}$ See Peter H. Solomon, Law and Courts in Authoritarian States, International Encyclopedia of the Social \& BeHAVIORAL SCIENCES 427-34 (James D. Wright ed., 2015).

${ }^{34}$ See Richard H. Pildes, The Inherent Authoritarianism in Democratic Regimes, in OUT OF AND INTO AUTHORITARIAN LAW (Sajó ed., 2002).
} 
to politically sensitive issues." ${ }^{35}$ In Eastern Europe, legislative politics were based on the reality of unified power of the autocrat; without the tradition of separation of power, every sphere of law became subordinated to the central political will. Consequently, judges were bound to the political center through the text of the law. At the same time, this legal binding gave the judiciary a relatively effective shield against arbitrary and personal influences.

Modernization and the institutionalization of legalism introduced the police-state and the uniform rationality of court practices, in the name of rationalization and bureaucratic efficiency. The whole region of Eastern and East-Central Europe's enlightened despotism during the legal modernization was not efficiently limited by strong professional autonomy, education, and cooperation. Professional autonomies and cooperation among legal professions could moderate the authority of the central power by elaborating techniques of self-defense, counterarguments, and alliances. ${ }^{36}$ A legal complex is a result of a historical development based on autonomies and professional education. And vocational education based on autonomy needs a solid theoretical foundation.

In Hungary, despite the strong effects of the German culture and science, the Rechtsstaat as a basic theoretical concept was eminently missing. Von Mohr and his school were unknown in the Hungarian legal science and jurisprudential adaptation came to a halt at Jehring and neo-Kantian theory. ${ }^{37}$ Even Kelsen was left out of the canon.

During the legal modernization process from the 1880's in Hungary, rational codification continuously bumped into the ideologically conceptualized national legal traditions. Voluntary reforms had to battle with existing normative relations and social interests regularly opposed foreign adaptation with the help of Eastern ethnic nationalism. The conservative idea of historical legal school (Volksgeist), which was very popular in the interwar period, and especially the organic development thesis, ${ }^{38}$ could be used for defending the status quo. ${ }^{39}$ Adherence to historical traditions of the nation was used as an ideological argument against the adaptation of legal institutions with foreign origin. In the battle of enlightened legislation versus compilation, most of the time the collected national usages-as Werbőczy Tripartitum in Hungary-won the case. Collected ancient national normative habits in systematized form transformed into law. The force of patriotic code, the inseparableness of the nation and the state, protected inner development of the normative system from the foreign influence, enforcing and following domestic traditions expressed the necessary loyalty to authorities. As in Russia during the 19th century, in Hungary too, the "invention" of national legal tradition vehemently denied the possibility of borrowing Western institutions. Despite these historic barriers, legal codifications have changed the Hungarian national law into a modernized legal system with formal elements. From this historical conjunction an autocratic legalism remained for much time, transcending political systems. The non-Western legal culture meant state-centered legality and instrumentalist formalism, where formal institutions are used as pure technology, while the idea of authority remained traditional, not constrained by formalism or universal values. Practicing lawyers, first of all judges, had to serve the state interest, which preceded individual rights or general values such as human rights. The judges took guidance from the prosecutors, the true stewards of the official and exclusive meaning of the law.

\footnotetext{
${ }^{35}$ See Tatiana Borisova, The Emergence of the Legality in Russia, 1800-1918 (2016) (Academic Dissertation, University of Turku. Faculty of Law, 16.12.2016), https://www.utupub.fi/bitstream/handle/10024/129875/Borisova_DISS_2016.pdf? sequence $=2$ \&isAllowed $=\mathrm{y}$.

${ }^{36}$ See Terence Halliday, Fighting for Political Freedom: Comparative Studies of the Legal Complex for Political Change (Lucien Karpik \& Malcolm Feeley eds., 2007).

${ }^{37}$ See Peter Sólyom, Jogászi módszer és politika. Fejezeter a Német Közjogtudomány Történetéböl [Legal Method and Politics. Chapters on the History of German Public Law] (2016).

${ }^{38}$ According to this idea, every legal reform must be based on the national sources and folk traditions.

${ }^{39}$ See Kálmán Kulcsár, Modernization and LaW (1989); József Szabadfalvi, Transition and Tradition. Can Hungarian Traditions of Legal Philosophy Contribute to Legal Transition?, 96 ArCHIVES FOR PHIL. L. \& Soc. PHIL. 337-47 (2010).
} 


\section{F. The Judiciary in Hungary Before Democratization}

After the late separation of courts from the state administration (1869), the institutional and mental autonomy of judiciary remained backward. Neither the legal theory nor historical circumstances gave proper context for the development of judicial independence and professionalism. ${ }^{40} \mathrm{After}$ World War II and before the communist takeover, the prosecution of war criminals, just like anywhere else in Europe, was a political duty. At the same time, the Stalinist elite, by the practice of the Peoples' Court, could use these processes for political cleansing. Almost 70,000 people were brought to trial, but severe convictions were handed down in a few cases. ${ }^{41}$ Meanwhile, the radical institutional restructuring and selection of staff were carried out according to the interests of the new communist party-state and following the pattern of the Stalinist judicial model. With the possibility of displacement of judges, the most important guarantee of independence was lost. A system of lay judges was implemented to ensure the democratic judicial practice. But the most important constitutional change which seriously redefined the status of judiciary was the 1949 Constitution and its "classical" principle of "unity of power." ${ }^{2}$ For the first time in Hungarian history, a written, basic law defined the functions of state organs and declared the rights and duties of citizens. This constitution, in a similar way to the other Soviet satellite states, was a faithful translation of the 1936 Constitution of the Soviet Union. In parallel with the institutional, legal transformations dictated by the Soviet experts, the whole legal staff including legal education was radically filtered by political reliability. ${ }^{43}$

Hungary after the World War II had to face another autocratic challenge- - the Soviet-Russian institutional and cultural legality. However, the East-Central European political and legal culture differs from this Eastern variant, the Hungarian mindset was by no means part of the Western legal tradition. This historical encounter had been taken place in a period when both the Soviet-Union and Hungarian state-structure have been transformed considerably. The Hungarian political and social elite during the Second World War lost their social credibility and prestige; none of the national aims could be reached, and state administration collapsed. The patrimonial, noble interests were proved to be inappropriate for any modernization, which was obviously necessary. The constitutional, political structure, the legal system, and the professions and institutions which emerged during the long 19th century could not give satisfactory ground for swift democratization. The Soviet political and legal system for that time was formalized by the help of the Stalinist institutionalization. The 1936 Soviet Constitution was suitable not only for borrowing legitimacy for the autocratic party-state, but for serving an enforced modernization pattern for satellite countries.

According to the principle of unity of power, the administration of the judiciary became strictly centralized in which the justice minister, through the court presidents who were appointed by him, controlled the system. ${ }^{44}$ This formal control was accomplished by direct orders, announcements, and informal guides. The peak of this direct ministerial control over court presidents was the reporting obligation. Later on, from the 1960s, the consolidation and softening of the

\footnotetext{
${ }^{40}$ Judicial autonomy refers to the freedom of interpretation, while independence is the guaranteed status of the judge and the institutional safeguards against outer influences.

${ }^{41}$ See Révész Béla, Politikai tisztogatások a Rákosi-időszak igazságszolgáltatási apparátusában [Political Cleansing in the Justice Staff During Rákosi-Period], in SuUm Cuique: Ünnepi tanulmányok Paczolay Péter 60. SZÜletésnaPja TISZTELETÉRE 413-25 (Fejes Zsuzsanna \& Török Bernát eds., 2016).

${ }^{42}$ See 1949. Act XX $\$ 2$ of the Constitution of 1949 (Hung.) (stating that “[i]n the Hungarian People’s Republic all the power belongs to the working people. The workers exercise their power through elected and accountable delegates to the people.").

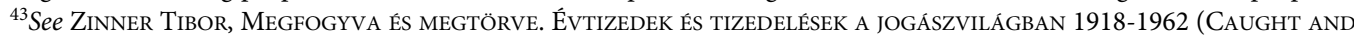
Broken. Decades and Decimates In the World of Lawyers) (2005).

${ }^{44}$ See 1954. Act II $\$ 17$ of 1954 on Judicial Administration; Ürmös Ferenc, A szocialista bírósági igazgatás kialakulása és típusai [The birth and types of the socialist judicial administration], ACTA Universitatis SzEGEDIENSIS De AtTILA JózseF Nominatae Acta Juridica Et Politica Tomus [University of Szegediensis, Attila József Unnamed Journal of Jurisprudence AND Politics] XXVI. Fa. 8., Szeged (1979).
} 
dictatorship was based on the professionalization, legalization and "deideologization" of the ministerial control. ${ }^{45}$

In the first epoch, after the communist takeover (1949-53), political attention turned to defending the new economic system by means of criminal law. The "wage-and-norm scams," "failing the compulsory delivery," "crime against plan discipline," "unauthorized slaughter," price speculation," and cases of "work discipline" have reached the masses of ordinary people. Omissions, hangings, and other disciplinary behaviors were signs of the everyday resistance. ${ }^{46}$ While the show trials concerned the political elite, these "petty" cases involved masses of workers and peasants. ${ }^{47}$ Because of the seriously detrimental conditions of the production, the official plans, which were issued in legal format and defended by criminal regulation, were nearly impossible to accomplish. Even "arbitrarily leaving the job" was a crime, threatened by serious consequences. Between 1950-52, about 7,000 people were convicted of violation of work discipline yearly and 53,000 people were convicted for a crime against public supply. The judiciary became a direct tool of the political will. Based on a Legislative Decree, ${ }^{48}$ the Supreme Court issued an ad hoc interpretation in 1951 stating that criminals violating work discipline could be punished according to crimes against the state, which means even the death penalty. ${ }^{49}$ The Supreme Court withdrew this harsh interpretation in $1954,{ }^{50}$ but in reality, despite the serious sentences in general, the judiciary mostly evaded this irrational interpretation during the everyday practice. ${ }^{51}$

In the first period of Hungarian communism, the independence of judges was seriously curtailed, and the political and administrative control over courts was intense and wide. ${ }^{52}$ State security and party organs directly manipulated the politically momentous cases, and all first instance decisions had to be sent to the state security office. The judicial process became one of the ideological tools of politics, and the reference to class struggle during the judicial process and in the sentences overtly liquidated the formal equality of rights. ${ }^{53}$ Despite this ideological and political corruption, the "educational" function of the legal process, the technical, dogmatic, and professional elements of positive law survived. ${ }^{54}$ Even in the 1952 labor discipline cases, judges tried to compensate for the brutality of the official expectations by using formal mitigating circumstances codified in the penal code. ${ }^{55}$

\footnotetext{
${ }^{45}$ See FLECK, supra note 28.

${ }^{46}$ See Varga László, "Pártunk nem ismerte a csüggedést, a kishitüséget" (Osztályharc az ötvenes évek elején), ["Our Party did not know the discouragement and piety." (Class struggle at the beginning of the 1950s)], in AZ ELHAGYOTT TÖMEG 1950-1956 (The Abandoned Crowd) (1994).

${ }^{47}$ See István Ötvös, Paralleled Stories Revived: Show Trials and Popular Front Policy in Hungary, 16 ANNALS OF THE UNIV. Bucharest, Pol. SCI. SERIES 39 (2014); ZinNer Tibor, AdALÉKOK A MAGYARORSZÁGI KONCEPCiÓs PEREKHEZ [ADDITIVES FOR THE Hungarian SHOW-Trials] (1988).

${ }^{48}$ 1950. 4. tvr (Hung.) (“About the criminal defense of the people's economy.”).

${ }^{49}$ LB. IV. 80208/1951 resolution (Hung.); Igazságügyi Közlöny 1951/14 (Hung.).

${ }^{50}$ LB. 1954 IV. elvi döntés (Hung.).

${ }^{51}$ See Gyekiczky Tamás, A fegyelem CsapdáJÁban [In the Trap of the Discipline] (1989).

${ }^{52}$ For the ministerial decrees which commanded the judicial practice, see HORVÁtH IBOLYA, IRATOK AZ igazsâgszolgáltatâs történetéhez 1-5 (Documents to the History of Justice) (1986); Palasik Mária, A JOGÁlLAMISÁG MEGTEREMTÉSÉNEK Kísérlete ÉS KUdARCA MAgYARORSZÁgon 1944-1949 (TRIAL AND FAILURE OF THE Creating Rule of Law in Hungary) (2000); Barna Ildikó \& Petö Andrea, A politikai igazságszolgáltatás a II. Világháború utáni Budapesten [Political Justice After the II. World War in Budapest] (2012).

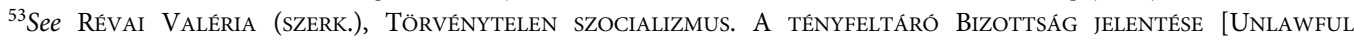
SOCIALISM. Report of THE FACT-Finding COMmitTeE] (1991).

${ }^{54}$ See Kulcsár Kálmân, Jogszociológia (Sociology of LAW) (1997); Kulcsár Kálmán, A jog szerepe a társadalmi változásokban - a jog változása [The Role of the Law in Social Changes - The Change of the Law], in JoG És TÖRVÉNYESSÉG [LAW AND LEGALITY] (Petrick Ferenc ed., 1985).

${ }^{55}$ See GYEKICZKY TAMÁs, A MUNKAFEGYELEM JOGI SZABÁLYOZÁSÁNAK TÁRSADALMI HÁTTERE AZ 1952-ES ÉV MAGYARORSZÁGÁN [The Social Background of the Legal Regulation of Work Discipline in 1952] (1986); Harmathyné Horváth ANNA, TÁrsadalmi tulajdon és bÜntetópolitika [Social Property and Criminal Policy] (1988).
} 
The professional elements were under constant challenge, because the official program of the Communist Party was based on a total recalibration of state bureaucracy with the primary aim of political reliability. ${ }^{56}$ The continuous, campaign-like judicial selections reached all legal professions and lasted until the beginning of the 1960s. This existential uncertainty was officially justified by the ideological bounds of the lawyers to the old, capitalist power and the liberal mindset. But the political aim was to construct a new "democratic" intellectual class. In 1953, with the Communist Party still dissatisfied with the process of loyalty-making, a Party decree blamed the politically unreliable justice apparatus and urged a new wave of removals of disloyal judges. ${ }^{57}$ The political intent of creating loyal judges and prosecutors had manifested in establishing the "Judicial and Prosecutorial Academia," in which after some months of ideological and little legal technical training reliable young workers and peasants got a "legal degree." They were the first appointees in the leading positions in justice system. When the first year graduated at the ELTE University in 1953, the Academia was no longer needed, and all "academic lawyers" were obliged to enroll in evening training at the University. The first cohort graduated at ELTE in the same year and was divided centrally into the most important, leading positions. ${ }^{58}$

The year of 1953 was the year of political detente, and its consequences were directly reflected in the court statistics: A considerable drop in ideological, political crimes. But the conservative turn also left a direct mark on the statistics. ${ }^{59}$ The severe retribution after the 1956 revolution was managed through the judicial system. ${ }^{60}$ Statutory justice, which was meted out without any due process protections, was performed by military courts until November $1957 .{ }^{61}$ After this immediate reaction, a parliamentary decree reestablished the People's Courtas a special council of the Supreme Court which could revise the sentences of ordinary courts and was staffed with lay people. $^{62}$ Between November 4, 1956 and the end of 1963, more than 26,000 people were sentenced by different courts. More than ninety percent were sentenced to light imprisonment of less than five years, and 367 people were sentenced to death. ${ }^{63}$

\section{G. Relative Judicial Independence}

In the socialist legal theory since 1936, judges are independent and subordinated only to legal norms, at least according to the text of the constitution and textbooks. But the judiciary cannot be independent from the politics of the state and from high state organs because the unity of power-instead of the separation,- - served the most important basis of state theory. According to the socialist jurisprudence judges must defend the principles and aims of the state. ${ }^{64}$ Independence can be comprehensible only in individual cases. To understand the scope of judicial independence in non-democratic Hungary, this theoretical starting point must be taken into consideration. The judicial reformulation of autonomy and independence was an emancipatory battle in different political and institutional contexts, but the result remained necessarily relative.

\footnotetext{
${ }^{56}$ See IBOLYA, supra note 52.

${ }^{57}$ Id. at $399-401$.

${ }^{58}$ Interview with V.M. county court judge by Zoltán Fleck (April 4, 1998).

${ }^{59}$ See Mádai Lajos, A bírósági statisztika 1951-55. Évi eredménYei [Results of the Judicial Statistics 1951-55] (1991).

${ }^{60}$ See Benkes Mihály, Az 1956-os Magyar Forradalom [The Hungarian Revolution of 1956] (György Litván ed., 1992); Tankönyvkiadó, 1992The Hungarian ReVolution of 1956. ReForm, Revolt and RePression 1953-1963. (Gyorgy Litvan, Janos Bak \& Lyman Howard Legters eds., 1996).

${ }^{61}$ 1956. 22. Sz. Tvr. On the statutory justice (Hung.); 1957. 4. Sz. Tvr. On accelerated criminal procedure (Hung.).

${ }^{62}$ 1957. 25. Sz. Tvr. On People's courts (Hung.).

${ }^{63}$ The exact numbers are still in dispute. See Szakolczai Attila, Az 1956-os megtorlás során kivégzettek számáról [On the Numbers of Executed During the Retaliation After 1956], PEREK https://perek56.hu/ords/th/r/1051/files/static/v38/Az_ 1956_os_megtorlas_soran_kivegzettek_szamarol.pdf (last visited Aug. 19, 2021). Those Executed during the Reprisals after the Revolution see 1956 Institute, YeARbOoK III. BUdAPEST (1994).

${ }^{64}$ See Hans Kelsen, The Communist Theory of Law (1955).
} 
Among the dense web of organizational bonds around the judiciary the court hierarchy played a considerable role during "actually existing socialism"-this term was used to denote the difference between ideology and practice. At the highest level of the judicial hierarchy, the Supreme Court judges were selected along a peculiar mixture of seniority and reliability under the auspices of the President of the Supreme Court who was elected by the Parliament. The Supreme Court exerted principal control over the judicial activity and issued sentencing guidelines as normative management tools mandatory for judges. ${ }^{65}$ Besides this quasi norm-making authority, the President of the Supreme Court could initiate a superappeal against any sentence and could bring any case within his own control. ${ }^{66}$ Judicial arguments against the official interpretation were unlikely because in this context, any doctrinal evasion from the official interpretation could have jeopardized career promotions. Closer to the everyday life of the judges, lower court presidents exerted administrative control over judicial work. Middle-level, county court presidents decided over selection and promotion of judges, specified the working conditions, gave rewards, commenced disciplinary process, and distributed cases. The position of county court president was on the "cadre scope list," which means that the higher level of Party confirmation was needed for appointment. The traditionally strong position of county administration was the main route of political influence because court presidents belonged to the informal power center of state and party leadership, which also included the county police chief, the chief prosecutor, the president of the local chamber - soviet - the secretary of the local executive committee, and party leaders. Among these circumstances, the risk of judicial dissent or fighting for greater autonomy was high. But as we will see, some took this risk.

As the highest administrative responsibility was with the Minister of Justice, the apparatus with its Judicial Department regularly monitored the practice of the judiciary, which meant that administrative control spread to sentencing, trial leadership, and adherence to legal policy. Ministerial committees regularly visited courts in general or to monitor a special task, for instance, sentencing, imposition of penalties, or the consistency of judicial argumentation. ${ }^{67}$ Beside this administrative control, the Ministry of Justice played an important role in rule-making processes, as ministerial decrees directly affected the judicial status. However, the main channel of political influence in individual cases was elsewhere - in the informal party connections to court administration. ${ }^{68}$ The parallel dependency structure of state and the party is a well-known feature of the communist regimes, but most of the time these lines were inseparably entangled.

The prosecutorial office in the communist systems is the center of the socialist legality. The heirs of Vishinsky, the dreaded lord of the Stalinist state, were formidable players of legal procedures. Prosecutors were the central agents of legality, and the legality control extended to the activities of judges, too. As the content and meaning of the term socialist legality changed, so changed the effects of the prosecutors on the judiciary. However, the political role of the prosecutorial office in the new authoritarian state is revived. ${ }^{69}$

Beside these institutional relations, another branch of problems concerning judicial independence was the social status and prestige of judges. Until the fall of the Communist regime, the

\footnotetext{
${ }^{65}$ See 1949. Act XX of $1949 \$ 38$ (Hung.) (stating that “[t]he Supreme Court of People’s Republic of Hungary exercises principled control over the judicial functioning and adjudication of all courts. The Supreme Court establishes guidelines and makes decisions in principle that are binding on the courts.").

${ }^{66}$ See 2012. Act II on Administration of Courts $\$ 42$.

${ }^{67}$ See Interview with Z. K. county court judge by Zoltán Fleck (October 6, 1998).

${ }^{68} \mathrm{Id}$.

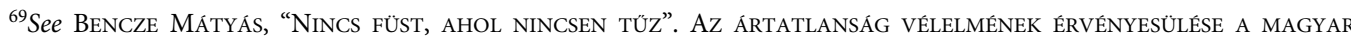

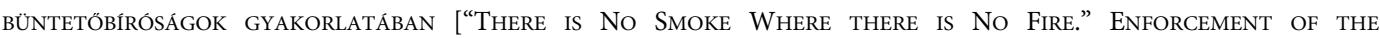
Presumption of Innocence in the Practice of Hungarian Criminal Courts] (2016); Kádár András Kristóf, A VÉtKesség VÉlelme [The Presumption of Guilt] (2004).
} 
judicial salaries and other material conditions were poor. ${ }^{70}$ The average salary of lawyers in the early 1970s was 4,410 Ft per month. ${ }^{71}$ The highest average salaries were for attorneys and lawyers working in the ministries, and the lowest were for council lawyers and university lecturers. ${ }^{72}$ When the wages of lawyers started to differentiate as a consequence of the economic reform from the end of 1960s, the low judicial salary became the main cause of contra-selection and strong fluctuation. ${ }^{73}$ Despite the stubborn adherence to the power structure and ideology, the real exercise of power softened and thus the free scope of judicial staff widened considerably.

\section{H. Judges Defending Themselves: Fighting for Autonomy}

After the end of the retaliation following the 1956 revolution and the political amnesty, from the mid-1960s the relation of the political center to the judiciary has changed with the elimination of "telephone justice," 74 where political leaders dictate judgments. ${ }^{75}$ However, the institutional guarantees against the administrative influence were also missing, as in most cases there was no chance of judicial control over the function of investigative authorities, despite the fact that these organs often disregarded the procedural rules. In the political system, which moved from the Stalinist years - in Hungary, the Rákosi regime in the 1950s - the tools of control also changed; the judiciary became depoliticized, in parallel with some distancing of the legal system from political ideology. The new legitimacy source became the stability and ideology-free everyday life, the regime had no need for courtrooms as symbolic or pedagogic sites anymore. However, at times of rising conservative sentiment, "economic crimes" such as misappropriation of public property and profiteering remained political tools in the hands of enemies of economic reform. The personal sacrifice was high, but the very nature of the regime and its relative distancing from the harsh and ideological classical communist legal policy remained stable. ${ }^{76}$

The institutional structure of the system kept its basic features: Judicial decision-making could be manipulated through ministerial control over courts, by the political role of the court presidents, by local party organs, and by prosecutors and the organizational hierarchy, especially the Supreme Court. ${ }^{77}$ The most interesting development in this period was the combination of growing legal rationality, the widening importance of normative regulation because of the marketfriendly economic reform and changing political legitimacy, and the modification of judicial attitudes concerning autonomy. The Hungarian socialist state under the logic of the economic reform changed the role of the general rules and pushed the direct instructions into the background. At the same time, the most important basis of legitimacy of the Kádár regime was the consolidation, the relative intactness of the institutions. ${ }^{78}$ By the help of this institutional formalism, judges could

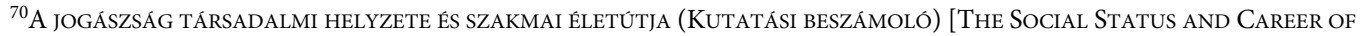
LAWYers. STUdy RePorT] (Pál Léderer ed., 1977).

${ }^{71}$ At that time, it was 110 USD. The first color television made in Hungary cost 32,000 Ft; a Skoda s-100 was 72,000 Ft at that time.

${ }^{72}$ Valuch Tibor, Magyarország társadalomtörténete a XX. SZÁZad második felében [Social History of Hungary at the Second Half of the 20th Century] 164 (2001).

${ }^{73}$ See FLECK, supra note 28.

${ }^{74}$ Telephone justice is the term used for direct political order for judges in particular cases during Communist rule. See Alena Ledeneva, Telephone Justice in Russia, 24 Post-Soviet Aff. 324 (2008).

${ }^{75}$ The system was similar in other Communist states. See David Kosař \& Samuel Spáč, Post-communist Chief Justices in Slovakia: From Transmission Belts to Semi-autonomous Actors?, 13 HAGUE J. RULE L. 107, 142 (2021).

${ }^{76}$ See PÜNKÖSTI ÁRPÁD, KIVÁlASZTOTTAK [The Selected] (1988). Pünkösti’s sociography is about the socialist cooperative presidents who were then charged with various economic crimes, but most of the time they were fined lightly or acquitted by the court. However, their career and personal life broke down.

${ }^{77}$ See Kahler Frigyes, Joghalál Magyarországon [Death of the LaW in Hungary] (1993); Zinner Tibor,

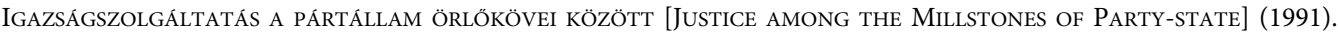

${ }^{78}$ See Berend T. Iván, Terelöúton. Közép- És Kelet-Európa 1944-1990 [On Detour. Central and Eastern Europe 19441990] (1999).
} 
show a moderate resistance against the attempts to political or personal influence in specific cases. Acts of resistance were no way heroic or highly risky, rather they became the normal consequence of the normalization of the regime, a generational shift and the strengthening importance of legal regulation. The forms of resistance remained strictly individual; no signs of collective solidarity emerged. ${ }^{79}$

As the general administrator of the court system, the Minister of Justice had strong control over the personnel policy and the financial status of judiciary. Beside these administrative tools, the Minister was responsible for the general legality of judicial practice and uniformity of legal interpretation. ${ }^{80}$ As such, ministerial apparatus consisting of judges appointed for ministerial status organized regular inspections over certain judicial fields. Compared to earlier periods, from the 1970s, the professional competence of the judges working in the governmental bureaucracy could really help the sitting judges_- political control had turned into professional guidance. Thus, the political control exerted by the Minister was mostly exhausted in selecting and appointing judicial leaders who were the key figures during socialism. Even deputy county court presidents had to be party members, but this condition did not apply for local presidents. At the middle management level, in the case of professional leadership, the professional qualities and loyalty were mixed a peculiar way. In decisions on judicial promotion, the professional qualities played a definite role, although in some cases decision-makers required party membership. ${ }^{81}$ However, this requirement became more and more anomalous. There were no signs of open resistance, but judges who did not want to join the party gave up promotion, at least temporarily.

Most of the political interferences within the judiciary were channeled through court administration, mostly by court presidents. Thus, the administrative hierarchy could be saturated by political intentions and interests; the level of judicial independence depended on the relationship to the court president. Presidents decided over the evaluation of judicial work, promotion, allocation of cases, awarding, and defining the general conditions of judges' work. They belonged to the local political and administrative elite and thus functioned as intermediary factors between politics and the judiciary. According to the stories told by judges, ${ }^{82}$ enduring conflict with the president could seriously endanger one's judicial position, such that loyalty to the regime became identical to loyalty to organizational hierarchy.

At the same time, it was also quite specific to the Kádár regime that these same presidents could serve as a kind of gatekeeper against direct political pressures. They spoke the language of the authority but filtered the outer pressures; moreover, they had to lobby for the administrative and financial interests of the organization. According to interviews with judges, this double identity was itself the sign of the relevant change of the nature of political authority; judges themselves in several cases could use this channel for reaching rare goods such as phones, cars, or flat allocation. ${ }^{83}$

The most important branches of cases or tasks were continuously monitored by state and party organs. The informal "coordinative sessions" were regularly organized by the party and all the leaders of the legal organizations - county police chief, county attorney general, county president of the court, and the party leaders - had to appear and report on the actual issues. Coordinative sessions in the county levels were the adequate local organ of the central Coordinative Committee which decided on the most important political cases behind the scenes without any formality. These institutions were only discovered well after the transition. ${ }^{84}$

\footnotetext{
${ }^{79}$ See Fleck, supra note 28.

${ }^{80}$ See 1972. Act IV of 1972 on Courts (Hung.).

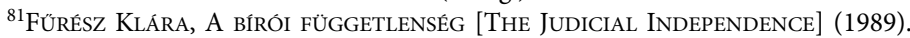

${ }^{82}$ See Interview with K.M., F. I., T..M. county court judges by Zoltán Fleck (July 1 to September 9, 1998).

${ }^{83}$ See Fleck, supra note 28.

${ }^{84}$ Révész Béla, A pártállami időszak ismeretlen hatalmi testülete: a Koordinációs Bizottság (1957-1988) [The Unknown Power Body of the Period of Party-state: The Coordination Committee], 76 ACTA UNIVERSITATIS SZEGEDIENSIS: ACTA JURIDICA ET POLITICA 87-399 (2014), http://w3.osaarchivum.org/index.php?option=com_content\&view=article\&id=2106\&Itemid= 2258\&lang $=$ en.
} 
The intermediary function of the president and the informal coordination among justice leaders were relevant signs of the political influencing, but also a considerable mark of the hardships of influencing judges directly. All the judicial interviews about this epoch reported a growing autonomy, which meant they could refuse any direct attempt of pressure, however they hardly refused the wishes of the presidents of the court.

Based on the continental career system, the influence of higher courts on the promotion of judges was high, as the normal channel of legal policy ideological and political aspects were flowing through the court hierarchy. Those judges who did not want to meet the political conditions, or the "political trustworthiness" for promotion, gave up career advancement. Interviews reported a kind of "protest of non-compliance."

The Party kept contact with court presidents, and according to the historical documents, ${ }^{86}$ in the second period of state socialism the political organs also dealt with such professional, administrative issues as overburden of the judges, litigation delay, and recruitment. These administrative problems were at the same time on the table of the state organs. However, according to the judges' recollections, the party's attention extended to the "moral defects" of the judiciary: Alcoholism, sexual "miscarriage," and so on. The pedagogic activity of the party has appeared in the usual "public training" sessions, where actual issues of legal policy were discussed. According to the interviews, these usual "head expander" talks were mandatory, but nobody took them seriously. Thus, the formal presence of the party was ensured because all courts had local party organs, but influencing the individual cases has lost its legitimacy from the 1960s. Judges could freely refuse direct pressures from the political organs without any risk. The presidents of the courts could mediate Important political aspects. Judges have developed sophisticated shields against the attempt of external pressures. If somebody tried to refer to higher political connections during the procedure, judges simply recorded it and put it into the report. This action made these trials impossible because the open influencing at that time was unacceptable even according to the formal political thinking. Influencing judges publicly became taboo; concerning the autonomy of judges this was one of the most important changes comparing to the previous epoch. But that is true, that judicial work discipline and worthy behavior were in the focus of the party's attention. The possible consequences of the "bad behavior" could be mitigated by political loyalty, but some additional work and impressive diligence could also help, as the court system has continuously suffered from overload. ${ }^{87}$ Judicial narrations spoke about the possibility of defending autonomy by neutral professionalism or turning inward. But the political indifference and the apathy for social issues made judges insensitive. Technical positivism could save judges from the administrative combativeness.

Due to ideological causes - the wages of state employees, for instance, could not far exceed the salary of a worker - the judicial system suffered from labor shortage and strong fluctuation. From the 1970s other legal jobs paid much better, and talented and diligent lawyers after some years of judicial work often looked for another job. When the twin problem of labor shortage and overload reached the administrative centers, the official reaction did not step out from the ideological cage; the phenomenon appeared in the thinking of the party and state leaders as a disciplinary issue. If a judge tried to seek another job during her judicial mandate, she committed a disciplinary offense. A disciplinary dismissal could stop her from getting any legal job. ${ }^{88}$ Without proper argumentation, the employer — at the highest level, the Presidential Council—-did not dismiss judges. This existential bound forced judges to seek alternative solutions; in case of judicial inaptitude, fleeing judges could leave their judgeships. Thus, some obtained medical certificates on mental incapacity. ${ }^{89}$

\footnotetext{
${ }^{85}$ See Interview with Zoltán Fleck (1996-1998).

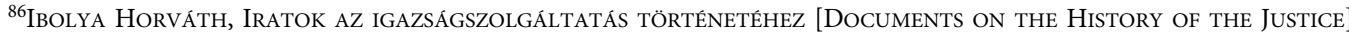
(Ibolya Horváth, Paul Solt, Gyozo Szabó, Janos Zanathy, \& Tibor Zinner eds., 1996).

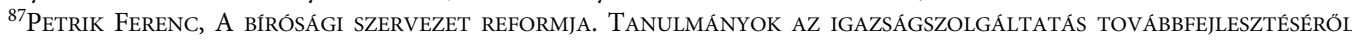

[The Reform of the Judicial Organization. Studies on the Development of Justice] (1988).

${ }^{88}$ See Interview with S.M. county court judge by Zoltán Fleck (April 28, 1998).

${ }^{89}$ See Interview with Z.T. county court judge by Zoltán Fleck (April 12, 1998).
} 
In the Kádár regime, judges worked in a contradictory environment: direct pressures were unacceptable, but also unnecessary. When some central political concept influenced the jurisdiction-for example, in the cases of economic crimes during the conservative wave between 1972 and 1976 - it could find its path without direct instructions. Almost every relevant matter was decided in the investigation phase; constructing or manipulating evidence could be hardly controlled by judges. In these political cases, the lighter sentences against the prosecutorial indictment were typical because usually only part of the offense could be proven. Formal, procedural rationality with the help of relative judicial independence saved the accused from the serious penal sanctions. However, the long criminal process itself served as punishment, such that the risk of being accused was enough to deter from "market trickery." Political concepts reached the desired consequences without direct manipulation of judiciary.

"Elsewhere they were comrades, here in the courthouse everyone was Mr. or Mrs., Mister President, Mister Judge. The typist was called Miss." 90 This symbolic feature signals that something has changed. Despite the limited independence of the judicial system in the socialist regime, the autonomy of judges became a value to be respected. All the influences have been channeled through administration, especially court presidents, who could control judicial work. Even court presidents effectively filtered the pressures because the judicial attitudes during the soft dictatorship contradicted these influences. However, the disciplinary tools, case selection, promotion, and other decisions concerning the context of judicial work gave hidden possibilities for influencing. There were different meanings and degrees of autonomy according to the organizational level, geographical place, and legal field. The political concept could be enforced with more success at higher levels, the selection of judges at the higher courts were less intact from the aspects of reliability. The higher we go in the judicial hierarchy, the more relative the independence could be. Criminal cases were more exposed to political intent than civil cases. Because of the importance of personal connections in the politics of the soft, Kádárist dictatorship, the level of autonomy and intactness sometimes depended on the personal nexus between political and court leaders at the local level. Persons matter.

Independence became valuable in the eyes of judges and they were reluctant to give it up: "I was poor, I was not appreciated a lot, all my tax evader accused laughed at me, all of them had better car then I ever have, but I could do what I like and no one could horn in my business," in the words of one of my interviewees. ${ }^{91}$

The exodus from politics and ideology was long, hard, and partly illusory because under the regulation of the party-state and under the official ideology of the unified power, the judiciary could be only relatively independent. Because the structural features of communist rule remained, the autonomy of the judiciary and independence of judges could not be complete. But some political intents were reached without harsh suppression of independence. The legal system and the social context seriously limited the judge's margin of maneuver and the general direction of jurisdiction; thus, political rationality has permeated the everyday work of judges.

In the first period of communist rule, ideological contents and direct political pressures did not allow space for professional or personal autonomies - higher interests trumped any independence. After political consolidation from the mid-1960s, arguments of judicial independence revived. The political legitimacy of the Kádár regime was based on the stability of institutions and depolitization of everyday life. Despite the structural and institutional continuity, defending some autonomy and being proud of it became possible. This second, so called soft epoch of Hungarian dictatorship, gave the possibility of preserving independence without spectacular resistance. Which means that judicial resistance during dark times has no relevant tradition in Hungary. Instead of judicial heroes, modern Hungarian judicial history might be characterized as relative autonomy in a softened authoritarian rule with limited risk.

\footnotetext{
${ }^{90} \mathrm{Id}$.

${ }^{91}$ See Interview with Cs. A. county court judge by Zoltán Fleck (April 13, 1998).
} 


\section{The Dynamic Meaning of Socialist Legality}

Socialist legality was the theoretical cornerstone of the communist regimes from the beginning, excluding the very first years after the 1917 Revolution. In the satellite states after the Second World War, the constitutional structures were built on the basis of the Constitution of Soviet Union (1936), which was formally similar to the contemporary Western European constitutions. This institutional similarity proved to be an important option for the later dynamism of the legalpolitical sphere because the facade of institutions and rights could be filled with some content if the interests of the political leadership did not contradict it. Moreover, in the hands of reformminded insider opponents and dissidents, the rights language could be put into use, demanding the real content of the constitutional text. The changing meaning of the term "socialist legality" mirrors this inner dynamism of the communist legal regime in Hungary.

The first epoch of socialist legality was burdened by serious paradoxes. It was defined in the official text as "revolutionary legality" and had a rather political grounding, serving the swift system change. All the lawlessness and miscarriages of justice were taken with reference to revolutionary legality. The will of the working class was embodied in the vanguard of the Communist Party and its actions. Legality had no dogmatic or jurisprudential background, it exhausted in an empty ideological reference. The story of socialist legality is filling the empty shell with different contents.

The most significant limit of this dynamism was the constant ideological basis of socialist state structure, the Leninist unified conception of authority. The principal institutional responsible for realization of socialist legality was the procuracy, the highly centralized, originally militant organization. As opposed to some communist states in Hungary, prosecutors did not wear uniform, but the strict hierarchical order and political function remained stable.

The basic element of the socialist theory of law was a material grounding of the legality concept, as its core was clearly political. When the political elite became relatively open for some softening, the content of socialist legality had changed toward formality, like in 1953 in Hungary. The governmental program of Imre Nagy acted against the lawlessness of the first years. After the Revolution of 1956, the concept gained a special double meaning: it signed a displacement from the harsh lawlessness of the epoch of "personal cult," and also as a weapon against the anti-communist criminals of the revolution. ${ }^{92}$ The "reconstruction of socialist legality" in this way has gained a legitimacy-making potential, stressing the necessity of political calm and depoliticization of everyday life. That became the basis of Kádár regime for a longer time. The decree of the Communist PartyHungarian Socialist Workers' Party-in December 1956 named one of the causes of the "counter-revolutionary" attempt as the former harsh breaching of the socialist legality by the party leadership..$^{33}$ Three years later the party decree ${ }^{94}$ on socialist legality defined actual tasks as enhanced protection of public property, fighting against "red tape," but the element of distancing from the past unlawfulness still occupied an important place in reasoning. From the end of 1962, as a preparation of the political amnesty in the following year, the main argument had changed: "the socialist legality is consolidated." "Our nation knows and appreciates that in our country everybody can live and work, who do not raise hands to the power of the people," said the decree of Party congress in $1962 .{ }^{95}$

Another change was noticeable after the economic reform from the beginning of the 1970s, the concept of socialist legality had gained more specific content, including: defense of the public and

\footnotetext{
${ }^{92}$ VII. Party Congress of Hungarian Socialist Workers Party (MSZMP), 1959 in A MagYar SzOCIALISTA MUNKÁSPÁRT HATÁROZATAi ÉS DOKUMENTUMAi 1956-1962 (Ágnes Ságvári Vass Henrik ed., 1964).

${ }^{93}$ Party decree in December 1956, in A Magyar Szocialista MunKáspárt határozatai És dokUmentumai 1956-1962 (Ágnes Ságvári Vass Henrik ed., 1964).

${ }^{94}$ VII. Party Congress in November 1959, in A Magyar Szocialista MunKásPÁrt határozatai és dokUmentumai 1956-1962 (Ágnes Ságvári Vass Henrik ed., 1964).

${ }^{95}$ VIII. Party Congress in November 1962, in A Magyar Szocialista MunKÁsPÁRT Határozatai És dOKUMENTUMAI 1956-1962 (Ágnes Ságvári Vass Henrik ed., 1964).
} 
personal property, labor, family and personal rights of the citizens, and rationalizing the public service. In 1979 a new decree of the Party defined the socialist legality with procedural guarantees and decentralization of state functions, widening of jurisdiction and developing the court system. ${ }^{96}$ Step by step the notion of socialist legality transformed into a limited rule of law. By the end of this decade, the adjective "socialist" disappeared from the concept of legality and gave place to the notion of constitutional legal order. From the middle of the 1980s signs of a dual process appeared; beside emphasizing the importance of legal modernization, fighting against bureaucratism, securing public safety, and combatting parasitism and oversized materiality came to the fore again. This change of emphasis mirrored the political division inside the Party: the reform wing and the conservatives. But it can be evaluated as a consequence of the economic crises; the old political logic revived and the antisocial elements are responsible for the problems. These phenomena can be exceeded by strengthening socialist legality. Until the very end of the regime, even at the dawn of the system change this see-saw or precarious dynamic remained virulent. In 1985, for the first time in the history of the socialist ideology, a party document mentioned the necessity of the rule of law. The political concept of Rechtsstaat was born, at last, in Hungary.

\section{J. Conclusion}

By a little more historical investigation, one can exceed the simple statement on missing rule of law tradition. The exact way of this shortage, the peculiarities of institutional development and its behavioral consequences, the issues I touched here could dispel the gloom around the contemporary backsliding of Hungarian democracy. Conceptual peculiarities, political context, and historical contingencies formed the path to the current problems. One sequence of this long journey from the birth of the modern Hungarian state lasts until the breakdown of communist rule. The next three decades from 1990 rewrote some aspects of the story told here, but institutional and mental processes did not disappear without a trace.

The authoritarian political tradition, the limited application of the separation of power principle, and the lack of the strong guarantees of judicial independence prevented the Hungarian legal system from forming a Rechtsstaat. Under this culture and practice of unlimited government, the position of the judge remained subordinated and the judiciary did not count as a limit of the executive, just as the Parliament did not check its power. The communist takeover promptly transformed the political and legal institutions on the Stalinist model. During the socialist era, judicial autonomy could not be developed, but in the second phase of communist rule judges achieved a relative personal independence. The meaning of socialist legality has changed in the political documents, but its real content did not threaten the party-state or the party's pervasive influence. It was only at the very end of its rule, in the middle of the 1980s, that a concept similar to the rule of law appeared.

Historical tradition of monolith public law and politics, subordinate organizational culture, underdeveloped jurisprudence, and the non-democratic and anti-liberal attitudes of the staff are the main explanatory factors for the persistent truncation of judicial independence. Any attempt to explain the success of the current destruction of the rule of law must consider the complexity of these factors.

${ }^{96}$ XII. Party Congress in January 1979, in Az MSZMP HATÁROZATAI És DOKUMENTUMAI 1975-1980 (1983). 